ported only two in 1968.

While it must be noted that, as in Veit's study, the contributions by other educational agencies and library schools not on the ALA list were not examined, nevertheless the developments in 1980 indicate some progress in increasing both the visibility and the educational opportunities in community college librarianship. Even with the combination of only modest growth ${ }^{5}$ and normal staff attrition, new community college librarians with specialized training, as suggested by Matthews and Edsall, will still be needed. At the same time we cannot expect all students to come

'Damon D. Hickey, "The Impact of Instructional Technology on the Future of Academic Librarianship," in Academic Libraries by the Year 2000 , ed. by Herbert Poole (New York: Bowker, 1977), pp. 34-39.

${ }^{2}$ Fritz Veit, "Training the Junior College Librarian," Journal of Education for Librarianship 9 (Fall 1968): 108-115.

${ }^{3}$ Charles Hale \& Shirley Edsall, "The Education of Community College Librarians," Journal of Education for Librarianship 16 (Fall 1975): 75- to library science programs with a comprehensive knowledge of different types of library employment possibilities. If we wish to continue and/or increase the visibility of community college librarianship as an option for new entrants to librarianship, then we must turn to a new set of questions-" What role should community college librarians, either individually or through their associations, take in the promotion of their specialty to future entrants into librarianship?" and "How can new partnerships with library educators be formed so that this visibility and educational opportunity is insured?"

\section{5.}

${ }^{4}$ Elizabeth W. Matthews, "Update in Education for Community College Library Administrators," Journal of Education for Librarianship 19 (Spring 1979): 304-31I.

${ }^{5}$ See information about enrollment projections in community colleges in Nancy B. Dearman \& Valena White Plisko, eds., The Condition of Education: Statistical Report 1980 (Washington: U.S. Department of Education, National Center for Educational Statistics, 1980), p. 24.

\title{
San Francisco Conference Highlights
}

San Francisco lived up to its reputation as the "Air-Conditioned City" by greeting conferencegoers with beautiful, cool weather. Despite the distance from the hotels to the Civic Auditorium, librarians kept a busy schedule of meetings, programs, tours, and informal discussions.

Among the conference events were tours of the City College of San Francisco and the Mission College LRC, excursions to local wineries, and nearly twenty program meetings. The excitement of annual conference was enhanced by hundreds of excellent San Francisco restaurants, art museums, the magic of Chinatown and Fisherman's Wharf, an incredible Gay Freedom Day Parade, the clear Pacific air, and the distant mountains.

\section{ACRL's Program Meeting}

On June 28 many members attended the membership meeting and program at the SheratonPalace Hotel. Penny Abell, 1980-81 ACRL President, launched the program theme of "Scholars and Librarians: Partners in Learning and Research" with some introductory observations, explaining: "During my tenure as ACRL president, I have attempted to concentrate my efforts on fostering closer relationships between academic librarians, individually and collectively, and their counterparts in higher education and research. Such interaction is crucial to the provision of adequate library and institutional support."
The theme speaker, Laura A. Bornholdt, vicepresident for education of the Lilly Endowment, spoke on "Shaking the Foundations" and provided some insight into what it is like to work for a foundation. She also suggested some ways in which librarians might expand their circle of foundation friends in the next ten years.

Afterwards, three pairs of librarian/scholar panelists reviewed their experiences with funded projects. John White, professor of philosophy and religion at DePauw University, described the ARL/OMS Small Library Development Project and remarked that "a good self-study team demands a good deal of trust and willing contributions on the part of both teaching faculty and librarians." A bibliographic instruction program for chemistry majors at the University of Rochester

\section{Dues Increase Referendum Passed}

ACRL members voted in favor of increasing ACRL divisional dues an additional $\$ 10$ in the July ballot. The final count as of July 30 , 1981 , was 1,320 votes for the increase, and 1,103 against, representing a 55\%-45\% approval.

The new rates will go into effect with the 1982 membership year. 


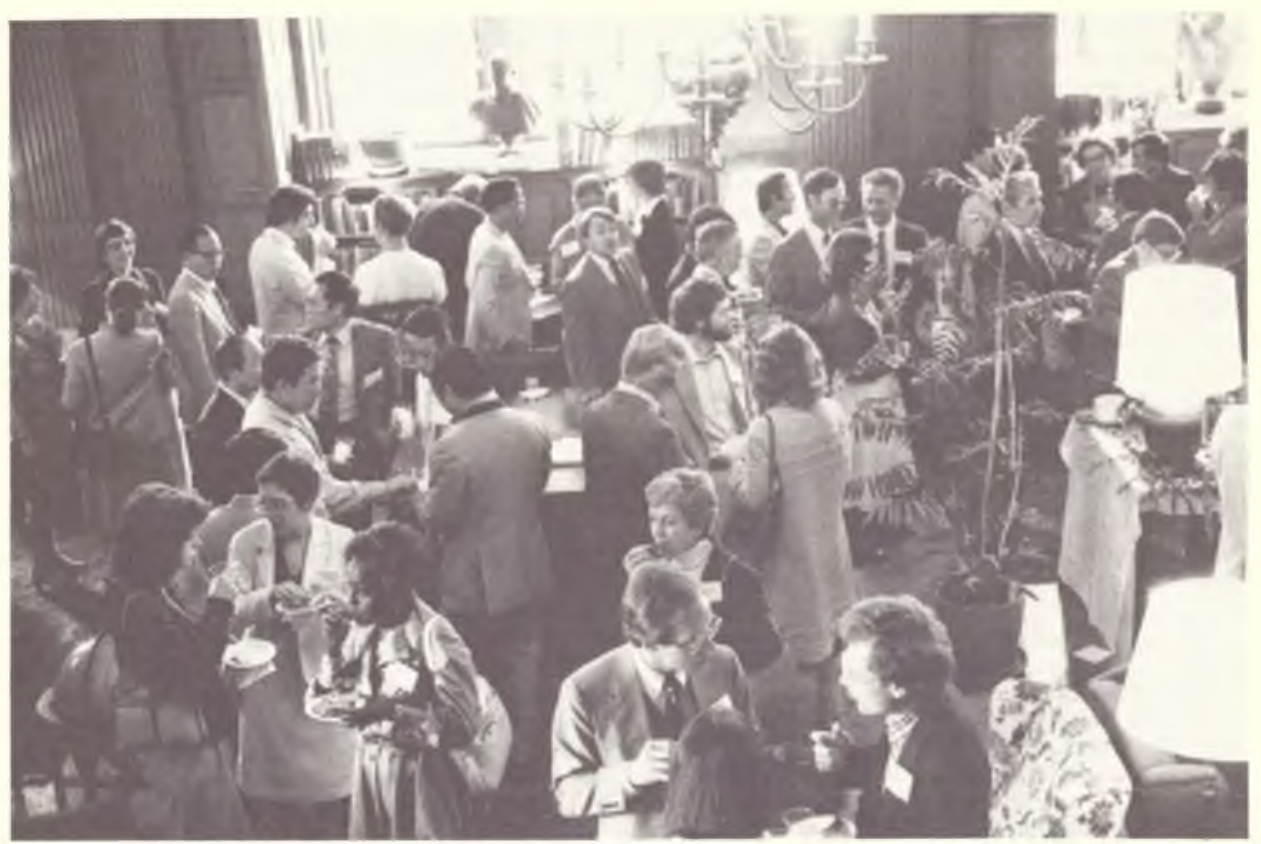

ACRL's well-attended reception in the Morrison Room.

Jane Scherr

was reported on by Arleen Somerville, science and engineering librarian. She noted that "students who have participated in our instruction are often the strongest advocates in convincing other faculty to use our information services." Judy Garodnick, from R. R. Bowker, and Andrea Hinding, director of the Walter Library at the University of Minnesota, then spoke about the co-operative production of a major bibliographic tool, Women's History Sources, published by Bowker.

The ACRL Reception was held afterwards in the Morrison Room of the Main Library at the University of California, Berkeley. Excellent Middle Eastern food, California wine, and music provided by a string quartet set the atmosphere for the reception, which was sponsored by the Baker \& Taylor Company. Beverly Lynch, university librarian at the University of Illinois, Chicago Circle, was presented the ACRL Academic Librarian of the Year Award by Baker \& Taylor.

\section{Asian and African Section}

The AAS panel discussion covered collecting and processing Asian language materials for the ethnic community, and servicing the information needs of the host community. Patrick Valentine, director of the federally-funded North Carolina Foreign Language Center, addressed the problems he faced in acquiring materials for a nonurban center. In contrast, Janie Lorentowitcz of the Toronto Public Library highlighted their wellorganized program to use the expertise of the University of Toronto to solve the technical problems involved in processing a wealth of foreign-language materials.

\section{Bibliographic Instruction Section}

"Will Bibliographic Instruction Survive the Online Age?" was the theme for the BIS program meeting. Among the speakers were Brian Neilsen, Northwestern University, who discussed alternative professional models for bibliographic instruction librarians in the Information Age, and Kristin McDonough, who described the multimedia bibliographic instruction package that has been developed at Baruch College.

The BIS Education for Bibliographic Instruction Committee held a separate panel discussion on teaching BI in library schools. Panelists were Joseph Boissé, Temple University Library; Elisabeth Eisenbach, UCLA School of Library Service; Paula Garrett, a library student at the University of Illinois; and Mary Reichel, Georgia State University Library. Boissé spoke in favor of an internship for library students in libraries with an established BI program, while Maureen Pastine, chair of the committee and librarian at San Jose State University, recommended BI courses in library schools to foster scholarship in BI theory. A lively question and answer period followed the presentation. 


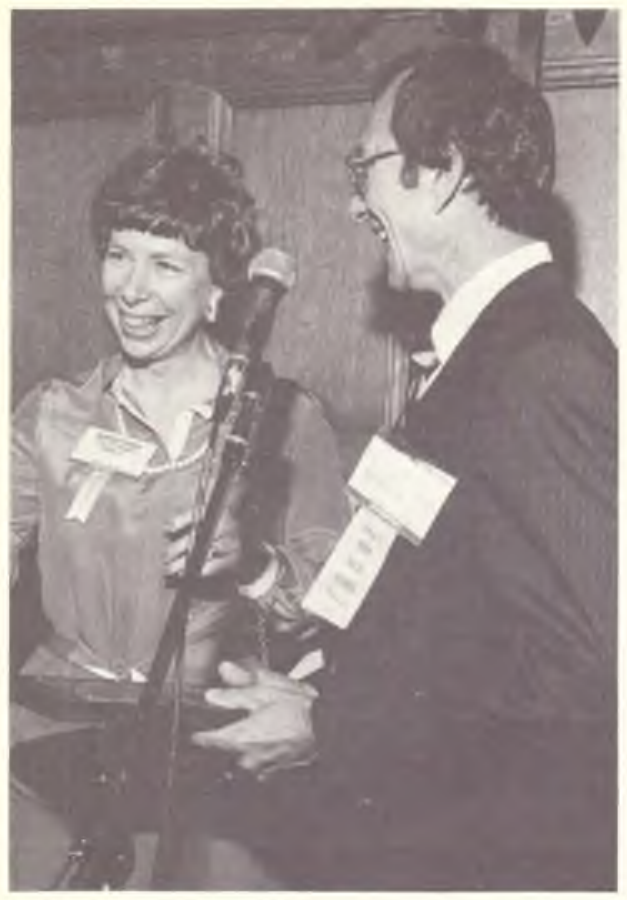

Beverly Lynch receives

Baker \& Taylor award.

Jane Scherr

\section{Continuing Education Courses}

ACRL launched its newly initiated CE program with four courses held June 25-26. The one- and two-day courses attracted $77 \mathrm{ACRL}$ members and non-members from academic, public, and special libraries across the country.

An overview of the consulting process was presented by James E. Ekendahl, Consulting Concepts, Inc., in "The Librarian As Consultant." Participants explored the many factors contributing to a successful consultant/client relationship.

Participants in "Planning and Procuring a Turnkey Library System" brought specific information about their respective institutions automation needs and worked with instructors Howard Dillon and Rob McGee to discover which of the many automation options best answered those needs.

In a spirited session Herbert S. White, Indiana University, offered information on management and communication in "Effective Supervisory Skills." Participants explored the dynamics of the supervisory role in a session punctuated by White's own dynamic and spritely style.

Participants in Keith W. Russell's "Career Planning and Development for the Academic Librarian: You Can Get There from Here!" assessed their career goals and objectives by means of a number of creative games and exercises related to career development.
In addition to course content, participants were pleased by the size of the classes, which were small enough to allow for maximum interaction between instructors and students. Participants were given the opportunity to suggest ideas for future ACRL courses.

C. Brigid Welch, ACRL program officer for continuing education, noted: "The success of these courses demonstrated members' interest in this type of educational experience. ACRL plans to continue to identify subjects that are of interest to its members and that are particularly suited to this kind of format-brief courses on specific topics that will enable participants to obtain more than an overview."

\section{Copyright Committee}

"Copyright: The A-V Dilemma" was cosponsored by the Copyright Committee, the Copyright Subcommittee of ALA's Legislation Committee, and the LITA Legislation and Regulation Committee. Speakers focused in particular on the fair use guidelines for off-air taping which are very near to being finalized.

\section{Law and Political Science Section}

LPSS co-sponsored the "Use of Local Documents in Reference and Research" program with ALA's Government Documents Round Table and RASD. Among the speakers were Alan Jacobs, Department of Urban and Regional Planning at the University of California, Berkeley, who stressed the importance of libraries as a vital forum for citizens to find documents on city plan-

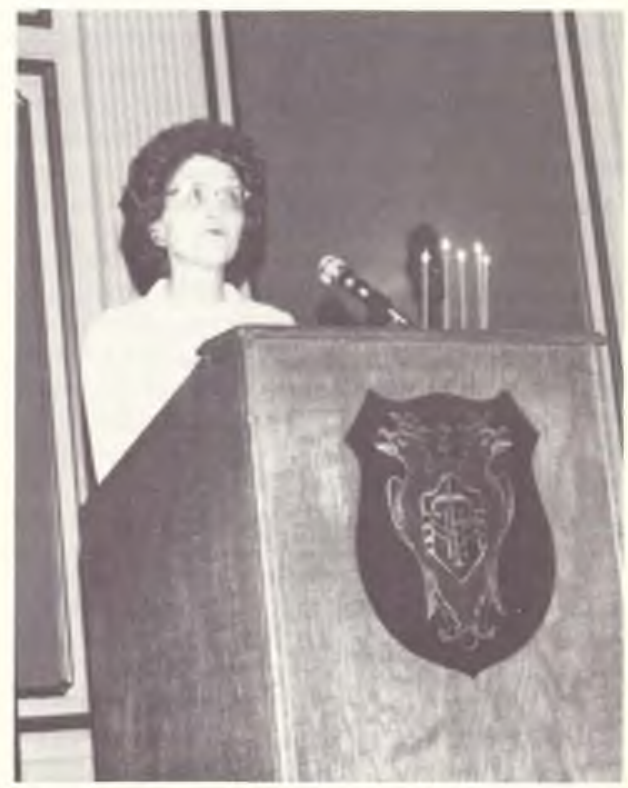

Laura Bornholdt addresses ACRL's program meeting. 
ning activities; and Ronald Heckert, from Berkeley's Institute of Governmental Studies, who noted the value of academic libraries in retaining local documents for public policy and historical research.

\section{Preconferences}

The ACRL sections held very successful preconferences on June 23-26. The overwhelmingly positive conference responses reflected the tremendous thought and careful preparation that went into each.

More than 160 conferees attended the ACRL Bibliographic Instruction Section preconference, "Premises, Problems, Promises: Views and Approaches to Bibliographic Instruction," at the University of San Francisco. Registrants heard speakers, participated in "Cracker Barrel" sessions on BI, and attended two of six challenging and informative day-long workshops.

The Community and Junior College Libraries Section's preconference dealt with "The Impact of the New Technologies on Learning Resource Center Programs." The two-day program consisted of speakers and small group discussions at the Sheraton-Palace Hotel and tours of the Mission College LRC and its computer system and the Paul Masson Winery. The $60+$ conferees appreciated the opportunity to take advantage of in-depth, small-group discussions.

The Rare Books and Manuscripts Section held its 22d preconference, "The Collection Builders: Booksellers, Book Collectors, Librarians," at the Holiday Inn Golden Gateway. The program's ten speakers addressed the development of research collections in the twentieth century and their influence. The more than 180 conferees took part in three receptions in addition to eight seminars coordinated by the Continuing Education Committee.

\section{Slavic and East European Section}

The SEES program was entitled "Past Developments and Future Prospects for AngloAmerican/Soviet Library Relations." Among the speakers were Robert Wedgeworth, ALA's executive director, who spoke on the role of ALA; and Marianna Tax Choldin, University of Illinois Library, who discussed the International Congress of Slavists at Garmisch in 1980.

\section{Undergraduate Librarians Discussion Group}

Panelists on "Current Problems in Undergraduate Library Management" included Jim Neal, University of Notre Dame, who described how an undergraduate library was disbanded; and Bill Whitson, University of California, Berkeley, who discussed Moffitt Library's weeding plan.

\section{University Libraries Section}

The joint ULS/CLS/CJCLS program was very well attended, completely filling the San Francis- co Hilton's Hilton Room. Theme speaker Robert Spencer, professor of history at Sangamon State University, spoke on enrollment trends in the 1980s; and M. L. Lunine, dean of undergraduate studies at San Francisco State University, discussed the role of college libraries in a future of "the mass society, the troubled economy, the seductive ideology, and the false dichotomy." Afterwards, the four topical presentations included "Implications for User Education" by Judith Pryor, University of Wisconsin-Parkside, who emphasized the need for long-range planning for BI at the institutional level; and Bart Lessin, Central Michigan University, who described the library support program at CMU which was designed to provide research assistance and document delivery to students off campus.

\section{Western European Specialists Section}

"The Library of Congress and the Future of Western European Collections," the WESS program, emphasized that Western Europe was the last region to be thought of in terms of area studies, resulting in a scarcity of information on the size and depth of subject collections in the field. Paul Mosher, Stanford University, updated the group on RLG's project to analyze the Library of Congress $\mathrm{P}$ classification to determine extent of holdings, and Ludwig Lauerhass, UCLS, representing the Seminar on the Acquisition of Latin American Library Materials, mentioned SALALM's proposed National Conference on Foreign Area and Language Librarians.

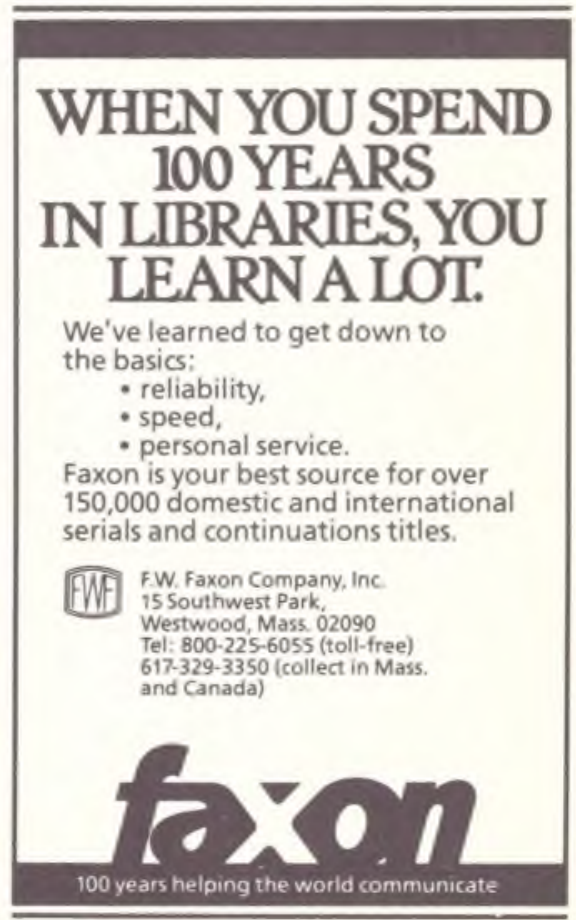

